\title{
Compulsory annuity purchase
}

Received: 28th May, 2002

\section{John Hayward}

is a senior pension consultant with Carr Sheppards Crosthwaite Limited. He was formerly a principal in the Inland Revenue Pension Schemes Office and has spent 14 years in pensions consultancy. He lectures and writes frequently on pension matters with regular monthly articles in Tax Journal since 1993. He wrote the original book, 'SSAS - SIPPS - FURBS', published by Tolleys as the leading work on small self-administered pension schemes, self-invested personal pension schemes and funded unapproved retirement benefit schemes.

Abstract This paper sets out the Inland Revenue's (IR) requirements for the compulsory purchase of an annuity to secure the retirement benefits of members of occupational and personal pension schemes. It looks at the origins of the requirement and changes that have since taken place including the income drawdown facility. The reasons for the requirement are examined together with the age limit of 75 . Finally, the Department for Work and Pensions (DWP) and IR's case for retaining the compulsory purchase of annuities and improvements to annuity products are looked at as well as the case for abolition of the requirement.

Keywords: compulsory annuity purchase; age 75; modernising annuities; consultative document; choice; abolition

\section{Current position}

It is an IR rule requirement that members of all personal pension schemes, including stakeholder schemes, retirement annuity contracts (RACs) and small self-administered pension schemes (SSAS) must purchase an annuity from a life office by age 75 to secure their retirement benefits from the scheme concerned. For all other occupational pension schemes, whether insured, self-administered, including public sector schemes, money purchase or final salary, contracted-out or not contracted-out, there is no such IR requirement. It is a matter for the occupational pension scheme concerned whether it wishes to include such a rule making annuity purchase compulsory or its rules offer members the choice of buying an annuity at age 75 in the open market. How has this situation come about?

\section{Origins}

When retirement annuities were first established in 1956 the member had to buy an annuity by age 70 at the latest from the proceeds of the policy. ${ }^{1}$ The age limit was raised to 75 in $1976,{ }^{2}$ shortly after a significant change to death benefits payable on death in service beyond age $75 .{ }^{3}$ In 1975 the IR required that if a member of an occupational pension scheme remained in service beyond age 75 and died in service without drawing any retirements benefits that the lump-sum death benefit passed automatically to the deceased member's estate. This was intended to counter capital transfer tax avoidance and gave scheme trustees no discretionary power as to the distribution of death benefits in such cases. This situation remained unchanged until 1991 when a range of normal retirement ages was set. In both 
of these measures the age 75 limit was apparently set.

\section{SSAS}

Since 1973 SSAS had been developing so by 1979 the former Superannuation Funds Office published its first general guidance on their administration. ${ }^{4}$ This guidance allowed members of SSAS to be paid a pension from the fund for up to 5 years following retirement before an annuity had to be purchased from a life office. The age 75 requirement was not imported at this stage. Instead, if a member retired at age 62 the annuity had to be purchased by age 67 or if they retired at 72 , the annuity would be purchased at any time up to age 77 .

It was not until 1994, after the creation of personal pension schemes, that the age 75 annuity purchase requirement was introduced into SSAS $^{5}$ by mutual agreement between the Association of Pensioneer Trustees and the IR. This agreement provided for annuity purchases to be deferred until age 75 , instead of for five years, and for a pension to be paid to a member meanwhile from the fund.

\section{Personal pension schemes}

The creation of personal pension schemes in $1989^{6}$ clearly borrowed from the current retirement annuity legislation in introducing the requirement for all members to buy an annuity from a life office by age 75 , but many felt it was influenced by the limits set on death benefits arising on death in service beyond age 75 . Certainly, the actual requirement to purchase an annuity was greatly influenced by the IR's experience of SSAS. So, from the commencement of personal pension schemes on the retirement of a member at any time between 50 and 75 an annuity had to be purchased from a life office.

It was not long before the financial constraints in the early 1990s and intensive lobbying by some life offices brought about a further change to personal pension schemes - the income drawdown facility. ${ }^{7}$ The SSAS changes in 1994 may also have brought about the change.

However, the increased cost of purchasing annuities, unfavourable annuity rates, inflexibility and lack of choice mainly contributed to the introduction of income drawdown in 1995. This became available after age 50 and allowed annuity purchases to be deferred until age 75 whether income drawdown was taken or not taken meanwhile.

\section{Later developments}

With the change of Government in 1997 the first moves towards the stakeholder pension regime commenced. The Government's Pension Review included a consultation exercise undertaken by the then DSS and part of this consultation exercise included the requirement to purchase an annuity by age 75 , albeit an IR requirement, but now apparently under DSS control. Indeed, in 1998 John Denham, as Minister for Pensions, answered a Parliamentary Question on this issue on behalf of the DSS: 'I can confirm that ways of translating pensions savings into retirement income are an important issue for the Pensions Review and one that we are examining'. However, when the IR later in 1998 published its consultation paper on the tax regime for stakeholder pensions, there was no mention about the possibility of abolishing annuity purchase deferral. Yet meanwhile as part of the Government's Pension's Review the DSS was apparently deliberating on how best to 
provide stakeholder pensions and that the restriction to buy an annuity by age 75 from a SSAS or personal pension scheme would have to go to allow greater financial flexibility.

While this consultation process was proceeding the IR introduced in 1999 the flexible retirement for money purchase occupational pension schemes in certain circumstances. ${ }^{8}$ If insured schemes adopted the flexible retirement provisions then the age 75 annuity purchase requirement had to be adopted also. Then when the stakeholder regime was introduced with effect from 6th April, $2001^{9}$ the legislation confirmed members of stakeholder schemes were required to purchase an annuity from a life office by age 75 although income drawdown would be available from age 50 to 75 . Both the DSS and IR on introduction of stakeholder pensions were notably silent on what had happened to the previous deliberations on the restriction to purchase an annuity by age 75 from a SSAS or personal pension scheme to allow greater financial flexibility.

The pensions industry subsequently became aware during 2000 and 2001 that the IR's and DSS's responsibility for the requirement to buy an annuity by age 75 had been taken over by the Treasury. All representations on the issue to the IR and DSS for a change were met with the response, 'It is a matter for Ministers'. The fact that this had now become a political issue is borne out by the joint DWP/IR consultative document issued earlier this year ${ }^{10}$ which puts the Treasury's case for retaining the age 75 annuity purchase requirement.

\section{Modernising annuities}

The Consultative Document explores ideas to help anyone who needs to buy an annuity to turn their personal pension savings into retirement income. The
Government is seeking to make it possible for all pensions savers to find suitable annuities that provide good value in a more flexible annuity market. The Government will not abolish compulsory purchase of annuities by age 75 , as it believes scrapping annuities would only benefit the well-off and that any tax relief should be given to people saving for their retirement rather than to those avoiding saving for a pension. This view that personal pension schemes are not a tax privileged moneybox has been maintained by the IR outwith the Consultative Document. ${ }^{11}$

The Consultative Document avers that annuities remain the right way of turning capital into income in retirement, without saying for whom, so one must assume it means for all members of the pension scheme involved. This is a very wide sweeping statement indeed and cannot be correct for everyone. A lot will depend on a member's age and the value of their fund.

However, the proposals for members to have choice, flexibility, transparency and control cannot be criticised if they are achieved following consultation and implementation. Having made the case that annuities are the way forward for members of personal pension schemes, stakeholder pension schemes, RACs and SSAS, the Consultative Document then sets out proposals for reforming them, to make the annuity market work better, for better understanding of annuities and income drawdown by members and for increasing the range of annuity products. This paper will look at the detail of some of these proposals.

\section{Consumer education}

It is recognised that scheme members need help to make suitable and reliable choices about using their pension savings to generate retirement income because of 
the many types of annuity available and their costs, and because income drawdown and the effects of mortality drag need to be better understood. Where members can obtain the necessary information and advice is addressed. The Financial Services Authority is therefore being encouraged to extend its coverage of comparative tables to include annuities. The life offices need to explain their products better. Choosing the right annuity is crucial as members are locked in to its terms for life. So the

Consultative Document asks a range of questions of how best this can be achieved. Unfortunately, it makes little mention of the direct costs to a member of obtaining financial advice to make such an important decision, but it does ask if it possible to deliver such advice in the workplace, eg by employers, trade unions etc.

Simplification of the underlying DWP and IR legislation is seen as part of the process of members better understanding the current complex situation when they come to retire. It is also envisaged that simplification and standardisation be brought into the stage at which the annuity choice has to be made, either with decision trees or standardising the forms used to describe annuities by life offices.

\section{Increasing flexibility}

At present the range of annuity products that can be used with pensions savings is limited. The IR will be taking an enabling power, probably in the Finance Act 2002, to allow different kinds of annuity to qualify. This is intended to offer members more choice and control over the annuities they buy. The proposals on specific products in this connection are short on detail, but new providers are to be encouraged to enter the market and thus provide greater competition. Indeed, there are some at present such as those proposed by the Retirement Income Working Party and London and Colonial (Assurance) plc. The Consultative Document proposes limited period annuities and transfers after the annuity had been purchased.

A limited period annuity would permit a member to draw money from their scheme funds to tide them over a temporary shortage of income, but only until they reach age 75 when they would have to purchase an annuity for the remainder of their life. The member could also choose to use part of their pension fund only to buy a limited period annuity. While a limited period annuity would lack the open-ended exposure to uncertainties regarding life expectancy, the risk could still be substantial as there is less time for the underlying investments to perform.

Currently, once an annuity is purchased from a life office it cannot be transferred. The annuitant is stuck forever with the life office concerned. So the proposal to allow an annuity once purchased to be transferred to another life office would provide a greater incentive to the provider to look after its customers better. The widening of choice after purchase is most welcome. But does the Consultative Document contain proposals to meet the Government's stated objectives of choice, flexibility, transparency and control? Many experienced pensions commentators think not. For instance, Dr Oonagh MacDonald, Director of the Retirement Income Reform Campaign and of the Financial Ombudsman Service, has commented that flexibility and choice are not fulfilled by the proposals in the Consultative Document. ${ }^{12}$ It is comments such as these and the DWP/IR's inflexible attitude to changing the compulsory annuity purchase requirement enshrined 
in the Consultative Document that can only fuel the growing lobby to abolish the compulsion.

\section{The case for abolition}

It is not intended here to propound the case for the abolition of the requirement to purchase an annuity by age 75 , but to set out the reasons for its abolition as presented by the various lobby groups. The reader can then be left to judge the validity of the Treasury's case for its retention as explained via the DWP/IR Consultative Document and via the contents of the following paragraphs.

It is important to understand first the various reasons for the Treasury's current stance. The IR some years ago argued that annuity rates could change in future and that trust-busting could occur if there was no compulsion to buy an annuity. The Treasury now argues that tax avoidance would occur especially involving higher rate taxpayers and that if the funds run out before death, members will fall back on the State for financial assistance. The IR's former arguments are countered by the abolition lobby's claims that annuity rates continue to fall and there is no likelihood of improvement, and the IR's concern with trust-busting, especially with SSAS, has been assuaged with the co-ownership of assets and banking signatories. ${ }^{13}$ To these counter-arguments can be added the fact that annuity rates have fallen by over a third in the last ten years and annuitants are expected to live with the consequences of a contract entered into up to 30 years previously when economic conditions were considerably different. Subsequent changes in the rate of inflation have a significant impact on the ability to maintain the annuitant's lifestyle. Index-linked annuities may mitigate the ravages of inflation, but they are expensive particularly because of the
Government's debt repayment schedule. Pensioners are being penalised because of this.

The tax avoidance and falling back on the State for financial assistance arguments can be met in various ways. No further personal or employer contributions should be permitted after age 75 as at present. Income drawdown within the 100 per cent and 35 per cent levels should continue, but if the member's fund is insufficient to support income drawdown at the minimum level then an annuity must be purchased at any age after 50 . Income drawdown at all levels must be justified. RACs would have to be afforded the income drawdown facility. All these aspects should apply to dependants too following the member's death. This would produce a stream of PAYE tax to the IR.

All personal pension schemes including stakeholder schemes and self-invested personal pension schemes (SIPPS) should be allowed to cross-subsidise the problems of life expectancy and therefore reduce the effects of mortality drag. The providers should have sufficient funds and members to enable them to do this and therefore continue paying pensions to their members for life. SSAS could continue to do so also provided the sponsoring company continued to operate the scheme and there were other continuing members. SIPPS would nonetheless be required to adopt the anti-trust-busting measures imposed on SSAS regarding co-ownership of assets and banking signatories.

\section{Choice and equitable treatment}

There is, though, more to the case for abolishing the requirement to buy an annuity before age 75 than countering the IR's and Treasury's arguments set out above. The age 75 cut-off point is purely arbitrary anyway. Why is someone 
suddenly overnight at age 75 plus incapable of arranging and looking after their affairs when the previous day they were so capable? Why not age 80 , or even older, with life expectancy increasing so much in recent years? There is an almost universal fear of having to buy an annuity from a life office because of the fear of an early death and the life office taking the 'surplus'. The number of individuals having to annuitise in future is bound to increase because direct contribution schemes are growing at such a fast rate. As they increasingly understand how their pension pot is growing over time, it is forecast more people will increasingly resent their assets being compulsory annuitised. ${ }^{14}$ Maybe 25 per cent of all adults will be affected. This resentment also extends to the cost of annuities which are far from transparent and understood by very few prospective annuitants. The gross mark-up to the annuity company averages just over 13 per cent. It is a real imposition on someone who does not need the benefit of the insurance element of an annuity. The annuitant rather than the life office is taking the risk. ${ }^{15}$

Finally, on choice and equitable treatment the abolitionist lobby feels its case is unanswerable. The Opposition Spokesman for Work and Pensions, David Willetts, commented in December 2001 that: 'The annuity debate was much broader than the inheritance of funds beyond death. It is about the freedom to save and for pensioners to do what they wish with their savings. The Government has had years to act on this. It is not up to politicians to design savings investments, but it is up to us to act on an anomaly in our current system'.
Alongside these statements, the contrast between the position of members of personal pension schemes, stakeholder schemes, RACs and SSAS and of members of large self-administered, insured and public sector schemes should be considered objectively. The latter, who hugely outnumber the former, are at an immense advantage when it comes to receiving a retirement pension. They do not have to concern themselves about buying an annuity at any age. Their pensions are paid by their scheme trustees, the life office or public body. The inequity of forcing a much smaller group to buy an annuity is stark indeed.

The debate on compulsory annuity purchase calls for equitable treatment and a greater element of choice for members of personal pension and stakeholder schemes, RACs and SSAS.

\section{References}

1 Section 22 (2) (b) Finance Act 1956.

2 Section 30 (2) Finance Act 1976.

3 Joint Office Memorandum No: 41.

4 Joint Office Memorandum No: 58, February 1979.

5 Joint agreement between Association of Pensioneer Trustees and Pension Schemes Office, February 1994.

6 Part XIV, Chapter IV, Income and Corporation Taxes Act 1988.

7 Schedule 11 Finance Act 1995.

8 Pension Schemes Office Update No: 54 30th June, 1999.

9 Schedule 13 Finance Act 2000.

10 Modernising Annuities: A Consultative Document, February 2002.

11 Paula Diggle, Head of Savings \& Pensions Policy, Inland Revenue, City Forum Conference, 'Pensions in 2002', 18th February, 2002.

12 City Forum Conference, 'Pensions in 2002', 18th February, 2002.

13 PSO Update No: 69, 29th August, 2000.

14 Piers Currie, Director, Aberdeen Asset Management, City Forum Conference, 'Pensions in 2002', 18th February, 2002

15 John Chown, Chown Dewhurst, City Forum Conference, 'Pensions in 2002', 18th February, 2002. 